\title{
ONCE AGAIN: NATIONALISM AND REVOLUTION
}

\section{James T. Siegel}

Benedict R. O'Gorman Anderson died in East Java on December 13. He was cremated and his ashes strewn in the Java Sea.

Anderson first came to Indonesia in 1962 as a graduate student at Cornell University writing a thesis on the revolution. Nationalist leaders were wrapped up in negotiations. Youth groups forced Sukarno to make a unilateral declaration of independence. Anderson mapped the youth whose violence and bravery made the march toward independence a revolution.

He moved the study of Indonesian politics from the story of diplomatic negotiations between states to identifying forces moving young men to wipe out recalcitrant elements impeding major changes in the movement forward. The word "revolution" means a radical change in relations of power between classes. Not much of that happened in Indonesia. "Revolution" was nonetheless an appropriate word because powerful forces were at work, associated not with a social class, but with those named pemuda (youth). "Youth," with its orientation to the uncertain shape of the future, was almost a synonym for "revolution."

One has to add, of course, "the Indonesian revolution." Not being a class revolution, the question remained what it was. The book makes clear that every "Indonesian" revolutionary followed a path that he or she thought was prescribed." Because of these actions, a nation appeared. Ben's next book showed how that could happen.

James T. Siegel is Professor of Anthropology and Asian Studies (retired), Cornell University.

${ }^{1}$ Benedict Anderson, Java in a Time of Revolution: Occupation and Resistance, 1944-1946 (Ithaca: Cornell University Press, 1972). 
Imagined Communities is written with suppleness, elegance, and with a pleasure so evident that the reader feels it throughout the book. ${ }^{2}$ That being so, one is prepared to enjoy the joke Ben tells in asking us to "imagine" a Tomb of the Unknown Marxist. The lack of a cenotaph for the unknown liberal is not that funny. Liberals, we all know, lack bodies anyway. There is nothing to mourn. Revolution is full of blood; liberalism only sheds the blood of others. The absurd "Tomb of the unknown Marxist" would, of course, contain a revolutionary. Revolution cannot create the conditions to memorialize itself. Nationalism, on the other hand, founds itself on memory, true or false. It institutionalizes itself, it memorializes its heroes, it replaces religion. What comes from revolution does not last. A nation formed out of revolution, Ben points out, takes the symbols of the old regime-the Kremlin most spectacularly-in order to appropriate the past and make a nation out of a kingdom. The new entity does not start over from nothing as revolutionaries often claimed was the case. The nation can be a lasting source of morality because it can hold on to memory, accurately or not. Revolution cannot do so. When it does, or tries to, it dissolves into nationalism or, to make itself effective, it builds a state. Nations concern themselves with death and immortality in a way that communism and liberalism do not. It seems that there is an opposition between revolution and nationalism. Trotsky's permanent revolution transcended national borders. Stalin, one of the important nationalists of his century, opposed Trotsky precisely on that point. Rootless cosmopolitans cling to revolution. Nationalists settle down. In every register the two are connected only to be set against each other. Revolution is put aside early in Imagined Communities in order that the nature of the nation can be explained.

At this moment revolution seems definitively out of the picture. No one in tune with the times is a revolutionary these days even if he or she radically opposes capitalism. It seems to go without saying that Ben was correct and his reintroduction of nationalism as a center of study was necessary. Nationalism itself came to seem a resolved issue after Ben's book appeared. Now that it is a political issue again, one thinks that it, and perhaps even revolution with it, will become a focus of scholarship. In any case, the relation between nationalism and revolution in Ben's work is worth looking at again. By 1983, the anticolonial revolutions were successful, but to what degree? Very few of them culminated in social revolution. Generally speaking, their success was limited to winning independence. After that it was a question, to use the phrase of the time, of "nation building." The University of Chicago itself established the now-defunct Committee on New Nations with luminaries such as Edward Shils and Clifford Geertz. In this period the two of them were speaking of "primordial" relations, an idea that certainly was contrary to Ben's. One sees, by comparison, how Ben made the nation look precisely historical, unnatural, and not at all primordial, dependent as it was on capitalism and modern technology.

It is all the more interesting then to ask why revolution had to be separated from the formation of nationalism so early in Imagined Communities. The putting aside of revolution was not a rejection of its importance, but of Ben's earlier interest. The book he published before Imagined Communities was called Java in a Time of Revolution. Nationalism was not centrally treated in that book nor was revolution the result of

${ }^{2}$ Benedict Anderson, Imagined Communities: Reflections on the Origin and Spread of Nationalism (London: Verso, 1983; rev. and exp., 1991, 2006). 
inevitable contradictions of class. That book starts not with a picture of Javanese economy and society but with an overview of the position of youth in Java. It is youth that was the motor of revolution, as is made clear in the title of Ben's thesis, from which the book was drawn: "The Pemuda Revolution: Indonesian Politics 19451946." Revolution described in that book came out of the radicalization of youth during the Japanese occupation. This was not done by sharpening contradictions until they demanded new solutions but by the exaggeration of old tendencies. Youth, always in a liminal or marginal position in Java, to use the terms of Victor Turner whose thinking influenced Ben at that moment, found their situation to be that of the entire society. In colonial and precolonial Java youth left home to wander, look for gurus, and enjoy freedom from the restraints of family. Japanese ideas of devotion, and Japanese military training, added the element of violence to this. Youth were prepared to resist the return of the Dutch.

To leave it at this would be to miss something important. At the same time Ben was writing his thesis he was also writing essays on Javanese culture that are unsurpassed amongst all the extraordinary things he did. Essays such as "The Idea of Power" or "Mythology and the Tolerance of the Javanese" opened another world to readers. ${ }^{3}$ The revolutionaries in Java in a Time of Revolution were radical in a way that is still hard to grasp from the outside but easier to take in when one reads the essays on Javanese culture. When, for instance, youth kidnapped Sukarno and forced him to proclaim independence, one asks why, if they had so much force and such determination, they did not take the leadership of the nationalist movement away from him to fill it with one of their own. The answer lies in the devotion to leaders that went with revolution in Java in a way that would have been incomprehensible in, for instance, eighteenth century France (before Napoleon, to be sure).

The revolution of Ben's book, in other words, was a singular revolution, not because economic and social conditions made it so but because of the unique quality of Java. This interest in uniqueness was put aside when Ben turned to the nature of nationalism. Nationalism was a function of capitalism; revolution was only sometimes so. Revolution could be singular; nationalism was a matter of exportable factors.

Nationalism and Revolution in Indonesia is the title of George Kahin's book. ${ }^{4}$ George directed Ben's thesis, and Ben nonetheless had the courage to revise George's views. When one reads George's book-and it is still worth the effort, after half a centuryone is hard put to find revolution. At most it is apparent as the implementation of nationalism. George tells the story of the scandal of colonialism, the reaction of Indonesians to it, and the efforts of nationalist leaders to find a solution to the conflict with the Dutch. None of this entails revolution action. Indonesians in George's book react to injustice as you or I would. There is nothing particularly Indonesian about them. Ben's thesis, then, revised George's by adding "revolution," but revolution was not defined as the overthrow of the Dutch, though, of course, that happened. Revolution, to Ben, indicated a source of thinking and action that was not available to

${ }^{3}$ Benedict R. O'G. Anderson, "The Idea of Power in Javanese Culture," in Culture and Politics in Indonesia, ed. Claire Holt (Ithaca: Cornell University Press, 1972), 1-69; and Benedict R. O'G. Anderson, Mythology and the Tolerance of the Javanese (Ithaca: Cornell Modern Indonesia Program, 1965).

${ }^{4}$ George Kahin, Nationalism and Revolution in Indonesia (Ithaca: Cornell Southeast Asia Program Publications, 1952). 
Kahin or to anyone, for that matter, without a Javanist's understanding. George pictured the intercourse of nationalist leaders and the Dutch. Ben showed youth acting outside such discourse, in their own terms, with motivations that took special effort to reveal.

This was not a socialist revolution. It needed, rather, to be understood through another strand of revolutionary thinking, one that said that revolution brought unforeseen and even unknowable elements into history. (One finds similar thinking, for instance, in Foucault when he supported the Ayatollah Khomeni.) There is almost a paradox in speaking, as Ben did, of liminality as a source of revolution. Liminality, as Turner spoke of it, was a feature of social structure, albeit of the gaps in structure. It was the place where the basic concepts, almost metaphysical concepts, or at least images, were revealed, on which social structure was said to rest. Marginality, its modern equivalent, was not entirely different. A basically conservative source served as an origin of revolution.

This apparent paradox is important, first, because it shows how the Indonesian revolution was a feature of Java itself and not of a general capitalist structure. And second, because it points to a certain indecipherability about the revolution itself, one embedded in something esoteric, and sometimes known only as an assumption to its proponents rather than being an idea subject to critical evaluation.

This particular revolution, as well as socialist revolution in general, is put aside in Imagined Communities. Revolutionary societies have no memory. To memorialize themselves they have to turn to the nation. The lack of continuity of revolution, its rejection of the past, leaves it unable to fix itself. Revolution, remembered, is thought of as victory, as the achievement of an end. At that moment it merges with nationalism. But revolution as Ben described it continues in the efforts of youth, the roots of whose radicalism is hidden.

There is another reason that revolution appears in Imagined Communities only in order to be repudiated. The early 1980 s was an era when the idea of revolution was being called into question. In particular, François Furet, a historian of the French Revolution and disillusioned leftist, brilliantly resuscitated Tocqueville, the Tocqueville of The Old Regime and the French Revolution (L'Ancien Régime et la Révolution, 1856). The gist of Furet's argument is that the changes attributed to revolution had already taken place before what is called "the revolution" had begun. Many bourgeois enjoyed the life of aristocrats while aristocrats, economically and socially, were often indistinguishable from bourgeois. This analysis of revolution was completed by British social historians who showed that the vaunted class basis of those who took part in the revolution was not clear. If the French Revolution, the prototype of revolution, was not a revolution, then one might think that revolution was a misleading term. "Revolution" was a word that only made the accurate tracing of social history difficult.

All the more reason, then, to reduce revolution to the mere instrument of nationalism, a matter of social history, important for its tonality at best. Or, alternatively, to make revolution appear as excessive, violent, and conflated with the "senseless" acts committed by bands of youth who seemed blind to their targets and whose motivations were not understood and were labeled incomprehensible. In the 
latter case, revolution was different from nationalism, producing ends, if any at all, that might lead to something other than nationalism.

In another short piece, this time on Pramoedya Ananta Toer's vignette called "Vengeance," the account of a haji suspected by youth of being a spy and beaten to death, Ben warned that Western scholars did not take sufficient account of the violence of the Indonesian revolution. Once again, the source of this violence remained opaque. Why was the haji suspect? Why is suspicion enough to justify murder? Where does this absolute conviction come from? The relation between this force and nationalism widened. All one could say was that, historically, the two acted in tandem during the Indonesian revolution. But when violence seemed without cause one had to find a place for this madness. That place was either revolution, but without the aims of nationalism, its own aims remaining to be understood, or the denial of the innovative possibilities of violence, calling it madness to avoid the necessity of explanation.

An opposition appears between revolution and nationalism when one has to think of violence. When the youths at the train station suspect the haji, they act on mere suspicion. But this is not to them suspicion, it is fact. They "know," somehow, that the man is guilty and they kill him. Just as in similar and quite common incidents in Indonesia today: someone is accused of theft, a group instantly forms, and the accused is frequently killed. So, too, with witchcraft. The puzzling feature is not the violence. It is the assurance people have that they are acting for reasons that are absolute. They make no investigation, and in particular do not attempt to demonstrate guilt in ways that might convince those who do not share their instantly derived certainty.

I link together witchcraft, the murder of thieves, and revolution, a certain revolutionary action, not only because of their common sense of absolute conviction but because they share both the breaking of the law and the making of it by the actors themselves. They make laws, but laws do not make a nation.

Nationalism in Ben's formulation means seeing oneself as the other. But revolution in the sense Ben used it in speaking of the Indonesian revolution is not that. It is ignoring the other as an equivalent of oneself. Revolution might also bring with it an imagined world, but it imagines the other only in order to reject him or her. The Indonesian nationalist leadership famously formulated and discussed independence not merely with each other but with the Dutch. But revolutionary groups throughout the revolution had no intellectual intercourse with the Dutch. Ben, in his multiple ways, once again, unearthed a striking account of an IndonesianChinese journalist who witnessed one of these groups at work as they killed Indonesian-Chinese, some of them the journalist's relatives, and many, one supposes, like the journalist himself, supporters of the revolution. But those who acted "knew" with certainty the necessity of their acts. Such knowledge comes when one ignores the other; when his or her opinion and thinking has no validity. When one is blind to him or, better, when he appears only as an obstacle so important it must be removed, he must be disappeared. Once again the actions of such groups appear incomprehensible to us who think from the point of view of the social. From that point of view one can 
only condemn such violent actions since they seem to shrink the boundaries of the social until it includes only a few.

It is another of Ben's great accomplishments not only to have reopened the study of nationalism, but to also have called attention to what can be called a revolutionary force that existed in the absence of the conventional notion of revolution. Javanese revolution as Ben understood it becomes a force in itself, no longer simply the work of radical youth misled by their swollen nationalist enthusiasm. Thus even possibly in opposition to nationalism, and yet far from the ideas of classical social revolution that dates from 1789 .

After the revolution, of course, nationalism remembers revolution. But it remembers it in transformed figures. Too often "the people" become "the mob," "the crowd," a mere source of disruption and the excuse for a strong military presence. Revolution remains an unassimilated element within the nation, one that continues to threaten it.

We have so far seen an opposition between nationalism and revolution, but of course the two are found together. Let us turn back to Imagined Communities to find a suggestion about the nature of their relationship. On page 25 of the latest edition there are three columns, each containing events occurring at the same time. Ben uses these columns to illustrate the assumption of homogenous time that informs the newspapers and the novel. He posits: "A quarrels with B. C and D make love" (column one). "A telephones C. B shops. D plays pool"; we are finished with column two. In the last column, "D gets drunk in a bar. A dines at home with $\mathrm{B}$. $\mathrm{C}$ has an ominous dream." The plot is filled in the text that follows: "Notice that during this sequence $A$ and D never meet, indeed may not even be aware of each other's existence if $\mathrm{C}$ has played her cards right." The point Ben draws is that, nonetheless, they exist in societies of such type that even without being acquainted they are nonetheless connected. Each is aware not of the particular existence of the other, but of his possible existence, one that is confirmed by "the omniscient readers" who make the connection. ${ }^{5}$

This is the plot of a novel perhaps. But Ben's point is that it is also a possible story in the newspaper, one that gains coherence only through a mentality whose assumption is the possibility of putting together events in "homogenous time." Putting them together not by analysis, but by identification of those involved and with those involved. Out of the possible presence of others the community is imagined, formed. It is not that there is a constant awareness of this possibility, but, as in the scenario Ben laid out, we see that at particular moments, a connection is or might be brought to light between persons who, nonetheless, may never meet.

There are two points to be made. First, "imagine" here is a mode of mental life. Experience figures only secondarily. The trajectory of native bureaucrats across the Dutch East Indies has something to do with the boundaries of Indonesia. But first there has to be the possibility of imagining someone somewhere else, unknown to oneself, but still thought to exist, with whom one can then identify. As Peng Cheah

${ }^{5}$ Anderson, Imagined Communities (2006), 25, 25-26. 
has pointed out, the modality is critical. And the modality comes on the model of the newspaper reader.

Critical to the modality is the possibility of imagining a third person, to put it in grammatical terms. One, that is, outside the conversation of the first two parties, the speaker and the listener. Outside what goes on between us, there are still others. They form a part of our conversation even if they are never mentioned. Whenever we speak, we exclude those not spoken to. And by that very exclusion, they take on a certain existence for us. In nationalism, such existence becomes more apparent: others unacquainted with us in some way offer possibilities for ourselves; we might be them; we share in some way their fate. With that the nation takes on form and substance.

This modality is historically given. It did not exist in fifteenth century Europe. It did exist in eighteenth century Europe. It is specific to time and place. And this means that it is subject to further modifications. Ben traced the formation of this community at the end of the period of decolonization when many new nations were formed. Now they are established. And being so one can see what has happened to the third person. $\mathrm{He}$ or she is still a member of the nation, or might be. But if one turns back to the history of independent Indonesia and in particular the history of the New Order, one sees nationalism taking a bad turn.

The New Order began with a massacre that rates rather high in the scale of such twentieth century events. What makes it different from, say, the Jewish holocaust, is that the Indonesian state turned against people who unequivocally belonged to the nation, without the ambiguity of the status of German Jews in the eyes of the Nazis. The Indonesian massacre, carried out under the Indonesian army, had popular support. No Indonesian specialist at the time foresaw this catastrophe. In retrospect, there were many explanations, usually attributing the killings and jailings to the rivalry between the Communists and the army joined by certain Muslims.

Political calculations are one thing. Popular support is another. How to account for it? We turn back to Ben's schema. The exemplary story he tells might be completed. C does not play her cards right. A finds out about D. A is then jealous, maybe for good reasons, maybe not. $C$ does not support this. She telephones $B$ and tells her what has been going on. A and B divorce. Or perhaps she only threatens to telephone $\mathrm{B}$. To prevent this, A murders her. Or maybe he murders the lover of his lover, $\mathrm{D}$. The plot can take various turns. They each depend on the reader, the member of the nation, having "complete confidence in [the] steady, anonymous, simultaneous activity" of the other members of the nation. And then acting. Does it take much to invert the signs and think of that "steady, anonymous ... activity" going on right now as ominous? ${ }^{6}$ Well, I think, yes, fortunately it does. The record of it doing so or not comprises a portion of modern history. But “... A and D are embedded in the minds of the omniscient readers" and this is an underlying assumption of the massacreinforming the conviction that the communists were engaged in a large scale plot to overturn the government and to murder their opponents. It is one possibility inherent in the establishment of the absent third person. The absent third person, the assumption on which the nation depends.

${ }^{6}$ Ibid., 26. 
The third person forms the structure of the nation, but, once again, the third person evolves. After the massacre, beginning in the $1980 \mathrm{~s}$, corpses began to be found on the streets and in the rivers. The "credit" for these murders was acknowledged by Suharto himself. One explanation of this returns to the ideas of revolution and changing notions of power. Any of these people could have been killed with the legal means available to the regime. That they were explicitly killed outside the law was, in one analysis, a claim of the state to the power of "criminality." "Criminality" itself, in this way of thinking, was an inverted form of revolution-the illicit making of the law-rather than the following of it. The political force of these killings drew on the mentality that establishes nationalism-on the assurance that there is an other and that he or she has something in common with "you," the reader. The state turns against its own citizens. It claims that those targeted are criminals and political subversives and it is believed. But these criminals are powerful. Then, by displaying the power to defeat criminals by criminal means, the state claims this power for itself.

The state itself claims the now sinister place of the other. A place made sinister by the gap between nationalism and revolution. But a place established in the foundation of the nation itself since, of course, the criminals are those I am telling you about, those not here, anonymous, their anonymity even guaranteed in papers that often pasted a black strip across their eyes.

These killings, as has been pointed out to me by Dan Lev and Joshua Barker, never really ceased, even after President Suharto left office. In Aceh, during the long decades of the "conflict" between the state and the armed bands who fought for an independent Aceh, again one found bodies in public places. But this time they were interpreted differently. Acehnese were unsure whether the army or the rebel forces were the killers. Usually these were said to be revenge killings. Usually the bodies were unidentified but it was nonetheless believed they were people who paid the price for collaborating with one side or the other. But no one was sure which side, as collaboration, if it actually took place, was always done in secret precisely for fear of revenge. No one could claim the power of criminality. No one could convincingly say, in effect, "I am the cornerstone of the nation, I did it, I have the power, here is the proof." After all, which nation-Indonesia or Aceh? And most people were not thoroughly attached to either side. Practically all Acehnese seemed to have supported the rebels because they offered the only alternative to the predations of the Indonesian army. But most of these supporters, even members of the rebel organization itself, thought that this organization, in its current state, did not represent them in any way except by its opposition to Indonesia. Only after Acehnese independence could the rebel organization represent the people. Meanwhile, Acehnese had "complete confidence in [the] steady, anonymous, simultaneous activity" of their copatriots of both nations, to use Ben's formulation. As a result they feared to leave their houses, and even when inside they did not feel safe. This is not at all the disintegration of nationalism. If anything it proves its strength. It is merely that the necessary third party no longer has a benevolent identity. One might think of this as nationalism against a nation.

This is by no means the only possible outcome of the story that Ben began. Fortunately there are others with happy endings. C plays her cards right. For that matter, this story of nationalism and revolution is not finished. In any case, it is 
evident that I endorse Ben's position: to understand nationalism, put revolution aside. But at certain moments it comes back because of the assumption that there is an other; the assumption that $I$ can take his or her place, changes its valence.

Ruth McVey and Ben also pointed out the separation of state and nation that occurred with the massacres of $1965 .{ }^{7}$ The state acted for reasons internal to itself rather than to further national interests. This explains why the army directed the massacres, but leaves the reason(s) for massive participation to be explained. For that, one has to turn back to nationalism, to its pathology originating in its capacity to generate suspicion. The force of the army linked to the power of the people, banished, killed, raped, imprisoned perhaps a million people, absurdly blaming them for the killing of eight generals. Without Ben's work, joined with McVey's, we could only think of this atrocity in terms that obscured its motivating forces, some specific to Indonesia, others not.

Ben Anderson was a polyglot fluent in the major European languages, classical and contemporary, as well as several Southeast Asian languages, in particular Indonesian, Javanese, and Thai, but others as well. Using them and his unparalleled knowledge, Ben continued to find the particularities of history that made a difference. He has been stopped, but he went far enough for one to think that his achievements began with "Indonesia" whether that nation was mentioned or not.

An obituary conventionally names the deceased's contributions as if they have been laid to rest, to be revived when necessary. Careful readers of Anderson's works will find themselves revived, living members of an organization without a form, joined in unimagined solidarity with others unknown to themselves, Ben first of all.

${ }^{7}$ Benedict R. Anderson and Ruth T. McVey, asst. Frederick P. Bunnell, A Preliminary Analysis of the October 1, 1965, Coup in Indonesia (Ithaca: Modern Indonesia Project, Interim Reports series, 1971). 